\title{
Berlin Devlet Kütüphanesinde Bulunan XVII. Yüzyıla Ait Bir Mecmuadaki Türk Atasözleri Derlemesi
}

\author{
Ahmet Naim ÇİÇEKLER* \\ Esma Baralı ÇİÇEKLER**
}

$\ddot{O} z$

Bir milletin kültürünü, hayat tarzını, geleneklerini ve dilinin inceliklerini en iyi şekilde yansıtan atasözleri; sosyoloji, psikoloji, felsefe, tarih, ahlak, folklor gibi birçok alanın inceleme konusu olmuştur. İncelediğimiz atasözleri Berlin Devlet Kütüphanesi Ms. Or. Quart 1988 ile kayıtlıdır. Derlenen atasözleri ise mecmuanın derkenârında yer almakta ve 422a-425a varakları arasında bulunmaktadır. Mecmua, Ahmed bin Musa tarafından İstanbul'da 1642 yılında derlenmiştir. İçerisinde 338 tane atasözü yer alırken deyim biçiminde herhangi bir kalıp söz bulunmamaktadır. İncelenen atasözleri bir abece sırasına göre dizilmediği gibi tematik olarak da düzenli bir sıralama görülmemektedir. Buna karşın tablo 1'de yaptı̆̆ımız tematik diziliş ise genelin \% 21 'ine tekâbül etmektedir. XVII. yüzyıla ait bu atasözlerinin toplumun muhtelif tabakalarından derlendiği kullanılan dilden anlaşılmaktadır. Atasözlerinde görülen çok sayıda sövgü sözleri ve kaba ifadeler toplumun bütün kesimlerinin kullandığı atasözlerinin yazıya geçirildiğinin göstergesidir. Seçkin tabakadan derlenen atasözlerine ise Arapça ve Farsça ibarelerin yer aldığı örnekler gösterilebilir. Bu da atasözlerinin belirttiğimiz gibi farklı tabakalardan alındığının başka bir göstergesi olarak yer almaktadır.

Anahtar Kelimeler: Türk atasözleri, Ahmed bin Musa, Berlin Devlet Kütüphanesi, Derleme, Kültür

\footnotetext{
* Doç. Dr., İstanbul Üniversitesi, Edebiyat Fakültesi, Türk Dili ve Edebiyatı Bölümü, Yeni Türk Dili Anabilim Dalı. Türkiye.

Elmek: acicekler@istanbul.edu.tr

** Yüksek Lisans Öğrencisi, Marmara Üniversitesi, Türkiyat Araştırmaları Enstitüsü, Türk Dili Bilim Dalı. Türkiye. Elmek: esmabcicekler@gmail.com
} 


\title{
A XVII. Century Compilation of Turkish Proverbs in a Mecmua in Berlin State Library
}

\begin{abstract}
Representing the language, culture, lifestyle, customs and linguistic nuances of a nation, proverbs have always been a case of study for various academic fields including sociology, psychology, philosophy, history, morality and folklore. The proverbs analyzed hereby are registered by Berlin State Library, Ms. Or. Quart 1988; whereas the proverbs compiled in this study are in the annotation section of the journal, recorded in between the folio numbered 422a and 425a. The journal was compiled by Ahmed bin Musa in Istanbul in the year of 1642. It harbors 338 proverbs, while involving no idiomatic phrases at all. The proverbs analyzed are in neither an alphabetical nor a thematic order. On the other hand, the theme-based order provided in Table 1 corresponds to $21 \%$ of the overall. Based on the language employed, it is understood that these proverbs, which belong to the 17th century, were used by various layers of the society. The vulgar language and the cursing vocabulary visible in these proverbs indicate that the proverbs used by all layers of the society were recorded. The proverbs collected from the elite class, however, can be traced in the examples that involve signs of Arabic and Persian, which also points out that the proverbs were derived from various layers of the society of the day.
\end{abstract}

Keywords: Turkish proverbs, Ahmed bin Musa, Berlin State Library, Compilation, Culture 


\section{Giriş}

Atasözleri, sözlü kültürün en önemli taşıyıcılarındandır. Hayatta karşılaşılan pek çok konu üzerine eskilerin tecrübe süzgecinden geçirilmiş hayat birikimini, kısa ve öz olarak sonraki nesillere aktardığı yol gösteren, nasihat eden kalıplaşmış ifadelerdir. Her dilde mevcut olan ve sosyoloji, psikoloji, felsefe, tarih, ahlak, folklor gibi birçok alanın inceleme konusu olan atasözleri, deyiş̧ güzelliği, anlatım gücü, kavram zenginliği bakımından çok önemli dil yapılarıdır. ${ }^{1}$

Şinasi, "Durûb-i emsâl ki hikmetü'l-avamdır, lisanından sâdır olduğu gibi bir milletin mahiyyet-i efkârına dalâlet eder."² derken aslında atasözlerini halkın bilgeliği olarak en öz şekliyle tanımlamıştır.

Aksoy ise atasözlerini "Atalarımızın, uzun denemelere dayanan yargılarını genel kural, bilgece düşünce ya da ögüt olarak düsturlaştıran ve kalıplaşmış biçimleri bulunan kamuca benimsenmiş özsözler"3 şeklinde tanımlamış, dil araştırmaları ve incelemeleri bakımından en önemli kaynak ve tanıklar olarak göstermiştir. Çünkü Aksoy'a göre atasözleri, sözdizim ve gramer hususiyetlerini, eski kelimeleri, bir bölgenin hususi kelimelerini, şivelerini, deyimlerini, telaffuzlarını içinde barındırır. ${ }^{4}$ Kemal Eyüboğlu atasözlerinin, halkın sağduyusunu yansıttığını, zekâsının imbiğinden geçen damlalar olduğunu, yağı ve kokusu ile ulusal kültürün dokularına sindiğini belirtmiş̧tir. ${ }^{5}$ Dilçin de bu sözlerin önemini "bir kavmin, ulus haline yükselişinin eskiliğini; ilk çağlardaki kültür ve medeniyet seviyesini, hasılı her bakımdan bütün benliğini tam manasıyla aksettirebilen başlıca aynalardan biri de şüphesiz atasözleridir" diyerek desteklemektedir. ${ }^{6}$

Atasözlerini sözdizimsel, biçimbilimsel ve anlambilimsel yönlerden inceleyen araştırmacılardan olan Doğan Aksan atasözü tanımını "çoğunlukla bir cümle biçiminde oluşarak bir yargı anlatan, kimi zaman ölçü ve uyakla, söyleyiş

1 Ö. Asım Aksoy, “Atasözleri, Deyimler”, TDA Yıllı̆̆ı Belleten, 1962, TDK Ya: 217, Ankara, 1988, s. 131.

2 İbrahim Şinasi Efendi, Durub-1 Emsal-i Osmaniye, İstanbul, 1302, s. 7.

3Aksoy, age, s. 37

4 Ö. Asım Aksoy, Gaziantep Ağzında Atasözleri, TDK, Ankara, 1941, s.6.

5 E. Kemal Eyüboğlu, Şiirde ve Halk Dilinde Atasözleri ve Deyimler, Doğan Kardeş Matbaacıllk, İstanbul, 1973, s. 24.

6 Dehri Dilçin, Edebiyatımızda Atasözleri, Klişecilik ve Matbaacılık T.A.Ş., İstanbul 1945, s.13-14. 
açısından daha etkili olmaya yönelen sözlerdir." şeklinde yaparken, Elçin ise atasözlerinin genellikle geniş zamanla, tavsiye verenlerin ise genellikle emir kipiyle kullanılmasına değinmiştir. ${ }^{8} \mathrm{Bu}$ tanımlar atasözlerinin genellikle bir cümleden oluşan söyleyiş açısından etkili, yani anlambilimsel olarak bir derinliğe sahip ve geniş zaman ya da emir kipiyle çekimlenen dilsel birlikler olduğunu vurgulamaktadır. Atasözlerinin genel tanımlarından ortaya çıkan unsurlardan biri de atasözlerinin akılda kalmalarıdır. Bu sebeple bir cümleden daha uzun atasözleri çok fazla kullanılmamaktadır. İncelediğimiz bu metindeki XVII. yüzyıl atasözlerinin çoğunluğu basit tek cümlelerden oluşurken birleşik cümleler de aynı şekilde kısa şartlı birleşik cümlelerden ve fiilimsilerle kurulmuş yapılardan oluşmaktadır.

Tülbentçi, söyleyeni bilinmeyen, fakat söyleneni halka malolmuş ata sözlerinin, geçirdiği türlü değişikliklere, bazılarının unutulduğuna, başka şekillere girdiğine veya yeni sözler ilave edildiğine değinerek "tama tama göl olur, düşman gözü kör olur" atasözünün "damlaya damlaya göl olur" şeklinde değişmesini ve dile öyle yerleşmesini örnek olarak göstermektedir. ${ }^{9}$ İncelediğimiz atasözlerinin de bir kısmı günümüzde hiç kullanılmazken bir kısmı başka formlarda günümüzde kullanılmaya devam etmektedir.

Karpuz ise atasözlerinin, diğer işlevleri yanında eğlenmek ve şakalaşmak gibi toplumsal-ruhsal boşalım araçları olduğuna değinmiş̧ir. ${ }^{10}$ İncelediğimiz mecmuada derlenen atasözlerinin müstehcenlerinin bu durumla ilgili olması muhtemeldir.

\section{Yüzyıl Sonuna Kadar Çeşitli Yazmalarda Bulunan Derleme Atasözleri}

$\mathrm{Bu}$ çalışmanın ana malzemesini oluşturan atasözü derlemeleri sadece bu mecmuanın içerisinde yer almamaktadır. 15. yüzyıldan başlayarak çeşitli mecmuaların içerisinde veya müstakil olarak atasözleri ve deyim derlemeleri karşımıza çıkmaktadır. Bunlardan bir kısmı Türkler tarafından bir kısmı da müsteşrikler ta-

\footnotetext{
7 Doğan Aksan, Her Yönüyle Dil Ana Çizgileriyle Dilbilim, Ankara, TDK Yayınları, 1998, s. 38. 8 Şükrü Elçin, Halk Edebiyatı Araştırmaları 2, Ankara, Akçay Yayınları, 1997, s. 422.

9 Fazıl Tülbentçi, Türk Atasözleri ve Deyimler, İnkilap ve Aka Kitabevleri, İstanbul, 1963, Önsöz.

10 Hacı Ömer Karpuz, "Türk Atasözlerindeki Yapısal Benzerlik Üzerine Dizibilim ve Dizimbilim Bakımlarından Bir İnceleme”, I. Dil, Yazın, Deyişbilim Sempozyumu, Denizli, 5-7 Nisan 2001, s. 236. (236-242.)
} 
rafından derlenmiştir. Bu bölümde üzerinde çalıştığımız eserin istinsah tarihine kadar olan atasözü ve deyim derlemeleri hakkında kısaca bilgi verilecektir.

Süleymaniye Kütüphanesi Fatih nr. 3543'te kayıtlı "Kitâb-1 Atalar" Türk atasözleri derlemelerinin en eski örneklerinden biri olarak karşımıza çıkmaktadır. Derleyicisi bilinmeyen bu derleme Hicrî 885 (1480-1481) yılında kaleme alınmış ve içerisinde yedi yüz civarında atasözünü barındırmaktadır. Atasözleri eserin 115b-136a varakları arasında yer almaktadır. ${ }^{11}$

Berlin Devlet Kütüphanesi’nde MS. Diez. A. Oct. 113’te kayıtlı eserin ne istinsah tarihi ne de müstensihi bellidir. İki kısım olarak düzenlenen mecmuanın birinci kısmında (vr. 1-26) Türk atasözleri alfabetik sırayla derlenmişken ikinci kısmında (vr. 26-39) herhangi bir alfabe sırası gözetilmemiştir. ${ }^{12}$ Âdem Ceyhan tarafından neşredilen bu atasözleri mecmuasında bulunan atasözleri ve deyimler tasnif edilirken Ceyhan, Türk'ü aşağılayan ve birden fazla yazılan atasözleri ile atasözü ve deyim olmayan kalıp sözlere çalışmasında yer vermemiştir. ${ }^{13}$

İkinci olarak Süleymaniye Kütüphanesi Es'ad Efendi, nr. 2733’te kayıtlı "atasözleri”, alfabetik sıraya göre derlenirken eserin 51a-67a varakları arasında yer almaktadır. Âdem Ceyhan eserin 15. yüzyılın ikinci yarısı veya 16. yüzyılın başında derlenmiş olabileceğini ileri sürmektedir. ${ }^{14}$

Üçüncüsü Staatsbibliothek, Berlin Devlet Kütüphanesi'nde Diez Fol. 25’te kayıtlı "Atalardan Kalma... Durûb-1 Emsâl ...” adlı eserdir ve 260 civarında atasözü ihtiva etmektedir. Yine Âdem Ceyhan tarafindan derlemenin 15. veya 16. yüzyıl ürünü olduğu tahmin edilmekte ve tek parça kağıda yazıldığ 1 belirtilmektedir. ${ }^{15}$

Dördüncüsü "Haza Durûb-1 Emsâl" adıyla kaydedilmiş bir derlemedir. Berlin Devlet Kütüphanesi'nde Diez A. 8. 121 sayıyla kayıtlı ve mecmuanın 3b13b varakları arasında yer alan atasözlerini ihtiva eden nüshanın, 1640 (H. 1050) yılında istinsah edildiği Ceyhan tarafından yapılan çalışmada belirtilmektedir. ${ }^{16}$

Beşinci eserin Türk Dil Kurumu Ktp. Yz. A 105/2' de kayıtll, aynı derleme-

11 Âdem Ceyhan, "Bazı Yazma ve Basma Türk Atasözü Derlemeleri”, Dil ve Edebiyat Araştırmaları, s. 4, Yaz 2011, s. 182.

12 Âdem Ceyhan, "Eski Bir Türk Atasözleri Kitabı”, Bir, sayı 9-10, İstanbul, 1998, s. 117.

13 Ceyhan, age, s. 119.

14 Ceyhan, "Bazı Yazma ve Basma Türk Atasözü Derlemeleri”, age, s. 186.

15 Ceyhan, "Bazı Yazma ve Basma Türk Atasözü Derlemeleri”, age, s.188.

16 Ceyhan, "Bazı Yazma ve Basma Türk Atasözü Derlemeleri”, age, s. 190 
nin TDK Ktp. Yz. A 361'da “Durûb-ı Emsâl-i Müsta 'mele”(Kullanılan Atasözleri) adıyla daha okunaklı bir nüshasının da olduğu ve 660 civarında atasözü, deyim, mısra, cümle, terkip ihtiva ettiği Âdem Ceyhan tarafindan belirtilmektedir. Derlemenin kim tarafından ve hangi tarihte yapıldığı bilinmemesine rağmen 16 . yüzyıldan sonra yapıldığı tahmin edilmektedir. ${ }^{17}$

Altıncısı Süleymaniye Ktp. Fatih nr. 5424'de kayıtlı olan "Min Darbi'lemsâl Ata Sözi Türkî Nice Nasîhatdur" adlı eserdir ve abece sırası gözetilmeksizin 17. yüzyllda derlendiği tahmin edilmiştir. 184 söz ihtiva eden bu mecmuada atasözleri 96b-98a varakları arasında yer almaktadır. Sadettin Buluç tarafından abece sırasıyla düzenlenip yayımlanmıştır. ${ }^{18}$

Yedincisi British Museum Harl. 5486 numara ile kayıtlı bir mecmuanın 1.-10. varakları arasında kayıtlı atasözü derlemesidir. Mecmua 1661 yılında derlenmiş ve derlenirken alfabe sırası gözetilmemiştir. ${ }^{19}$

Sekizincisi ise yine Âdem Ceyhan tarafindan "17. Asra Ait İki Kitapçı: Nasreddin Hoca Hikâyeleri ve Türk Atasözleri” adıyla neşredilen çalışmada geçen beş yüz kırkbeş atasözünden oluşan eserdir. Eser Berlin Devlet Kütüphanesi Diez A. 8. 121 numara ile kayıtlıdır. Atasözleri ve deyimler Hâzâ Durûb-ı Emsâl başlı̆̆ı altında ve 3b-13b varakları arasında yer almaktadır. ${ }^{20}$

Son derleme, çeşitli kütüphanelerde birçok yazması bulunan ${ }^{21}$ Güvâhî’nin Pend-nâme adlı eserinde geçen atasözleri ve deyimlerdir. Erenoğlu "Attâr'ın etkilerini taşıyan bir eser olarak aynı adı almış manzum bir öğüt kitabıdır. Türk kültürünün sahip olduğu atasözleri ve deyimlerin çokça kullanıldığı bu eser hem bir sözlük gibi âdeta o devrin bir atasözleri listesi olması hem de atasözleri ve deyimleri ölçülü bir şiir yapısı içinde kullanılmıştır"22 diyerek eserin önemini vurgulamaktadır.

17 Ceyhan, "Bazı Yazma ve Basma Türk Atasözü Derlemeleri”, age, s. 192. 18 Ceyhan, "Bazı Yazma ve Basma Türk Atasözü Derlemeleri”, age, s. 195. 19 Ceyhan, "Bazı Yazma ve Basma Türk Atasözü Derlemeleri”, age, s. 196. 20 Âdem Ceyhan, "17. Asra Ait İki Kitapçı: Nasreddin Hoca Hikâyeleri ve Türk Atasözleri”, CBÜ Sosyal Bilimler Dergisi, Cilt 9 S 2, Ekim 2011, s. 126.

21 Bk. Âdem Ceyhan, "Bazı Yazma ve Basma Türk Atasözü Derlemeleri”, Dil ve Edebiyat Araştırmaları, s. 4, Yaz 2011, s. 198.

22 Dilek Erenoğlu, “Güvâhî’den Günümüze Atasözleri ve Deyimler”, Turkish Studies, vol 2/4, 2007, s. 1153. 


\section{Berlin Kütüphanesi Ms. Or. Quart 1988 Numaralı Yazma- daki Atasözleri}

İncelediğimiz atasözlerinin içinde bulunduğu mecmua Berlin Devlet Kütüphanesi Ms Or. Quart 1988 numara ile kayıtlıdır. Derlenen atasözleri ise mecmuanın haşiyesinde yer almakta ve 422a-425a varakları arasında bulunmaktadır. Mecmua Ahmed bin Musa tarafından İstanbul'da derlenmiştir. İstinsah yeri ve müstensih bilgileri 523a numaralı varakta yer almaktadır. Mecmuanın istinsah tarihi ise 523b numaralı varakta şu şekilde geçmektedir: sene 1049 mâh-l Şevvâl'inden ibtidâ olunup sene 1052 mâh-ı Receb'inin ibtidâ gecesi, Cum'a gecesi ve hem leyle-i Regâib idi itmâmı vusûl buldı elhamdülillah ibtidâ ve intihâsı yigirmi bir ay oldı ve bu cem 'iyyet-i zîbânın cümle cetveli ve cildi dahı hakîündür, kusûrına nazar olunmayup dâmen-i lütf u keremler-ile setr eyleyeler ve's-selâm. Yani Ahmed bin Musa miladî Ocak/Şubat 1640 yılında nüshayı derlemeye başlamış, Eylü1/Ekim 1642 yılında ise mecmuanın derlemesini tamamlamıştır. Mecmuanın $1 \mathrm{~b}$ ve $2 \mathrm{a}$ varaklarında içindekiler listesi bulunmaktadır. 1b'deki içindekiler kısmı ana metne aitken 2 b'deki içindekiler kısmı ise eserin haşiyesine aittir. Lâkin incelediğimiz atasözleri bu içindekiler kısmında yer almamaktadır.

Bu yazmada incelenen her kalıp söz atasözü formundadır. Âdem Ceyhan'ın incelediği derlemelerde atasözü ve deyimler bir arada yer alırken bu derlemede deyim formunda herhangi bir kalıp söz bulunmamaktadır. Atasözlerini siralarken mecmua içerisinde bulunan sırayı esas aldık. Atasözleri derleyici tarafından öncelikle iki ana başlık altında sıralanmıştır (Sadece ilk atasözü istek kipi ile çekimlenmiştir.). İlk kısımda olumsuz bir yüklemle kurulmuş atasözleri 422a numaralı varakta yer almaktadır. İkinci kısımda ise nev'-i diger, fasl-ı devvüm başlığı altında, 422a-425a varak numaraları arasında demişler yüklemi ile kurulan atasözleri bulunmaktadır. Bu iki temel sıralama dışında atasözleri herhangi bir abece sırasına göre tasnif edilmemiştir. Aşağıdaki tablo 1'de görüleceği üzere sadece derlemenin belli bir kısmında aynı temadan atasözleri art arda gelmiştir. 338 atasözünün \% 21'inin belli bir temaya göre sıralanırken diğerlerinin herhangi bir tasnife tabi tutulmadığı görülmektedir. 
Ahmet Naim ÇIÇEKLER, Esma Baralı ÇIÇEKLER, Berlin Devlet Kütüphanesinde Bulunan XVII.

Yüzyıla Ait Bir Mecmuadaki Türk Atasözleri Derlemesi

\begin{tabular}{|c|c|c|}
\hline & Atasözlerinin Numaraları & Atasözlerinin Temaları \\
\hline 1 & $2-3$ & Yalnızlık \\
\hline 2 & $5-6$ & Kaza, kader \\
\hline 3 & $8-9$ & Çift başlilık \\
\hline 4 & $10-12$ & Aşk ve engeller \\
\hline 5 & $32-35$ & İmkânsızlık \\
\hline 6 & $56-58$ & Yemek \\
\hline 7 & $71-72$ & Uğur; uğursuzluk \\
\hline 8 & $74-75$ & Mum \\
\hline 9 & $87-94$ & Hayvanlar (köpek) \\
\hline 10 & $95-100$ & Delilik \\
\hline 11 & $111-118$ & Hayvanlar (kurt) \\
\hline 12 & $126-132$ & Hayvanlar (eşek) \\
\hline 13 & $135-137$ & Hayvanlar (kuş) \\
\hline 14 & $139-143$ & Hayvanlar (deve) \\
\hline 15 & $172-174$ & Hayvanlar (koyun; leylek) \\
\hline 16 & $180-182$ & Hayvanlar (domuz) \\
\hline 17 & $221-222$ & Para \\
\hline 18 & $230-231$ & Türkü yeren atasözleri \\
\hline 19 & $233-234$ & Davul \\
\hline 20 & $239-240$ & Bahane \\
\hline 21 & $268-271$ & Kuruluk \\
\hline 22 & $278-279$ & Hayvanlar (Serçe) \\
\hline 23 & 293-294 & Nasip \\
\hline 24 & $314-315$ & Erlik \\
\hline
\end{tabular}

Tablo 1: Mecmuada bulunan atasözlerinin temaları 


\section{Metin Oluşturulurken İzlenilen Yol}

İlk olarak atasözleri mecmua içerisindeki sıraya göre Latin harflerine aktarılmıştır. Sıra sayı numaraları ve noktalamalar da tarafımızca eklenmiştir. Okunayaman yerler ... ile gösterilmiştir. Metinde muhtemelen ciltleme sırasında meydana gelmiş hasarlardan dolayı silinmiş yerler de bulunmaktadır. Bu kısımlarda kalan ve okunamayan kısımlar da silinmiş şeklinde gösterilmiştir. Silinmiş veya müstensih tarafından unutulan yerlerin bir kısmı ise tarafımızdan tamamlanarak [] arasında yazılmıştır. Atasözleri içerisinde yer alan sövgü sözlerinin ilk hecelerindeki ünlüler ise * işareti ile gösterilmiştir. Metindeki eklerin imlâsında iki yol izlenmiştir: Bunlardan ilki imlâsını açık olarak gösteren ekler (+(n)Uñ, -Ur, + dUḳ) buna göre, Diğer ekler ise Yavuz Kartallığlu'nun ${ }^{23}$ eserindeki oranlara göre yazılmıştır. 


\section{METIN}

[422a] Bu faṣl dahı̆ atalarsözi beyānundadur, zikr olunur

1. İș odur kim Allah oñara.

2. Yalıñuz țaş dīvār olmaz.

3. Yalıñuz elin sesi çıḳmaz.

4. Kul hațāsiz olmaz.

5. Każāya ḳalḳan olmaz.

6. Każā vardım dèmez.

7. Atılan ok gerü dönmez.

8. İki pā[di]şāh bir vilāyete hükm ètmez.

9. İki arslan bir mīşde olmaz.

10. 'Āşık engelsiz olmaz.

11. Dünya dükenür, engel tükenmez.

12. 'Āşık yārsız olmaz.

13. Zamānsız hurūs ötmez.

14. Kil tepecik olmaz.

15. Kişi[y]e vațanı gibi olmaz.

16. Eski dost düşmen olmaz, eski düşmen de dost olmaz.

17. İyilik unudulmaz.

18. Ėvmek ile iş olmaz.

19. Kişi düşmānsız olmaz.

20. Ġammāz boynuna borç ḳomaz.

21. Delüklü țaş yerde ḳalmaz.

22. Kendü düşen ag̉lamaz.

23. Konuḳ umdugin yėmez.

24. Aḳacak ḳan țamarda țurmaz.

25. İstenilen şeyden hayr olmaz.

26. Korḳaḳ bāzergān așṣı etmez.

27. Kişi bir borcın bir s*kildügin unutmaz

28. Bilinmedük iş olmaz.

29. Cuhūd īmāna gelmez.

30. Merd-i mülhid tövbe-kār olmaz.

31. Ḥin og̉a[n]dan hayır gelmez.

32. Halāyık kadın olmaz.

33. Buṭ șı̣̂aḳ ile *m țār olmaz.

34. Çatal kazık yere girmez.

35. İki ḳarpuz bir ḳoltuḳda șı̇gmaz.

36. Bülbül gönülsiz irlamaz.

37. Gül dikensiz olmaz.

38. Yuva[r]lanan țaş yoșun țutmaz.

39. Kesilen baş bitmez, biterse de issine hayr etmez.

40. Güc-ile gökçeklik olmaz.

41. "Evimden çı̣" haḳḳımı vèr diyene cevāb olmaz.

42. Kimsenüñ haḳḳı kimsede ḳalmaz.
43. Su bulanmayınca țurulmaz.

44. Baba mālı og̀ıla hayr etmez.

45. Laḳırdıyla iş olmaz.

46. Kişi tükürdügin yalamaz.

47. Yalancınuñ işi oñmaz.

48. Şerī'at kesdügi parmaḳ acımaz.

49. Haḳk incilür, üzülmez.

50. Ecelsiz adam ölmez.

51. Aḳar șu yoșun dutmaz.

52. Kimse yog̉urdum ḳara dèmez.

53. Utananuñ og̉lı ve ḳızı olmaz.

54. Yazıcı kendüye kem yazmaz.

55. Tiryākī ādam olmaz.

56. Aç ayu oynamaz.

\section{Nev'-i dīger, faṣl-ı devvüm}

57. Evvel ța‘ām, andan kelām dėmişler.

58. Dost yemegin düşmen gibi ye dèmişler.

59. Yehūdīnüñ yegcegin ye evinde yatma dèmişler.

60. Söz ortanuñ ${ }^{24}$ eline, ni s*kime dèmişler.

61. Yaġırı olan ḳocunur dèmişler.

62. Otur da söyle dèmişler.

63. Kāfirüñ yegcegin yėme, evinde yat dèmişler.

64. La'net cuhūd șadaḳasında dèmişler.

65. Aç esner, toḳ geyürür dèmişler.

66. Boḳı yerinde yemek gerek dèmişler.

67. Geñez bahādur olur dèmişler.

68. Yılda bir ḳonşuna ț*şag̉un gerek [dėmişler].

69. Ḩādim șanmasun ne yavuz ol [aṣıl] ne yavaş ol bașil dèmişler.

70. ... silinmiş bir og̉lan olmış dẻmişler.

71. Keskin sirke kendü ḳabına żarar èder dėmişler.

72. Nekbeti bayrāmda bellü olur dèmişler.

73. [Āşināya] beñzemeyen ug̉ruluḳdur dèmişler.

[422b]

74. Hammama giren terler dèmişler.

75. Çerāḳ dibi ḳaranlıḳ olur dẻmişler.

76. Kişi yaḳduğı çerāg üstüne pervāne gerekdir dèmişler.

77. Șoḥbet șoñı dervīşlerüñdür dėmişler.

78. Hâầ durmışdan ḥācı șatılmış yeg dèmişler.

79. Kara yağız șoñra devir dèmişler.

80. İn ... bin diñlen dėmişler.

81. Hem țayın evine git hem țayıñ ögret dèmişler.

24 Metinde ن ile yazılmıştır. 
82. Sözi fikr eyle de söyle dėmişler.

83. Seyrāncı żarar etmez dẻmişler.

84. Kökü yegsiz olmasun dėmişler.

85. Güc-ile ḳoyuna giden köpek, issine hayr etmez dèmişler.

86. Köpegi öldürene sürüdürler dėmişler.

87. Nākesden iyilik ummak it s*kinden iyilik ummaḳ gibidir dèmişler.

88. İt dişi, țoñuz derisi demişler.

89. İt ürür, kervān göçer dèmişler.

90. Yeler ite menzil olmaz dèmişler.

91. Köpegüñ țaş yemesi or*spu og̉lına bağlıdır dèmişler.

92. Köpek aġzı kemük tutar dėmişler.

93. İt boḳu .... ...

94. Köpegüñ aḥmaġı țazı olur dėmişler.

95. Köpek-ile çuvala girme dèmişler.

96. Delü alacıyı sever dèmişler.

97. Delüye zinhā $[r]$ țaş añdırma demișler.

98. Ummadug̉uñ ${ }^{25}$ țaş baş yarar dèmişler.

99. Delüye ne $\mathrm{s}^{* \mathrm{k}}$ ne s*kil dèmişler.

100. Dīvāne-rā ḳalem nīst dèmişler. ${ }^{26}$

101. Delüden uṣlu haber dėmişler.

102. Yorg̉ana göre użat ayaġın dėmişler.

103. Çok yaşayan çoḳ bilmez, çok gezen çok bilür dèmişler.

104. Göz terāzu göñül mīzān dėmişler.

105. Komaduguñ yere el uzatma dėmişler.

106. Olursa hekīm olmazsa $s *$ kim dèmişler.

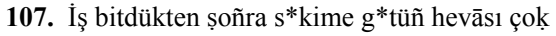
olur dèmişler.

108. Pazaruñ evvelce pekişdir dèmişler.

109. Ėl eliyle ḳuyuya inen geç çıḳar dèmişler.

110. Ėl atduğ 1 țaş uzaḳ gider dèmişler.

111. İşüñ yog்-1sa sāhid ol, borçuñ yog்-1sa kefīl ol dèmişler.

112. Kurda dėmişler kim "niçü[n] boynuñ yog̉undur?” işini kimseye inanmadug̉ındandır dèmişler.

113. Kurd yanısıra ḳuş da țoyar dèmişler.

114. [Çoban]sız ḳoyunı ḳurd yèr dèmişler.

115. [Tilkü] var baş keser, ḳurduñ adı [yaman]dur dèmişler.

116. Kurd ḳonşısını yėmez dėmişler.

117. Kurd ḳocayınca köpegüñ masharası olur dèmişler.

118. 'Adāletde ḳurd ḳoyunla yürür dèmişler.

119. Kurduñ, yüzi mübārek görmemesi daḩı

25 Metinde ن ile yazılmıştır.

26 Deliye kalem oynatılmaz. mübārekdir dėmişler.

120. Alet işler [el] ögünür dèmişler.

121. Ne ḳaranlıḳda [uyu] ne ḳara ḳura düş gör dèmişler.

122. Ėden bulur iñleyen ölür dėmişler.

123. Çalma kimsenüñ ḳapusın çalmasunlar ḳapuñ dèmişler.

124. Ekmegi ${ }^{27}$ deryāya at balık bilmezse hālıḳ bilür dèmişler.

125. Kִorḳ aḳṣaḳ-ıla körden dèmişler.

[423a]

126. Ere er gerek, bege beg gerek dėmişler.

127. Eşegi köpekçe bag̉la dèmişler.

128. Eşegi s*ken oṣ*rug̉una ḳatlanur dėmişler

129. İşde eşik işd $[\mathrm{e}]$ nerdübān dèmişler.

130. Her zaman ḩımār olmaz dėmişler.

131. Alçaḳ eşege kim gerekse biner dėmişler.

132. Eşegi dügüne oḳuyunca ya șu eksik olur ya odın dèmişler.

133. Kendü ḳanadıña uyar ḳuşla uç dėmişler.

134. Āzādsız köleyle baş ḳoşma dèmişler.

135. Varın vẻren yād olmamış dėmişler.

136. Kurḳ ḳarg̉aya bir taş yeter demişler.

137. Elmayı uran ḳuşum alur dèmişler.

138. Kuşı ḳuş-1la avlarlar dèmişler.

139. Yogurdına ḳıyamayan yemez boranı dėmişler.

140. Deveden büyük fil var dèmişler.

141. Deve gördüñ mi diyene köçegini dahı görmedüm dè dèmişler.

142. Deve ḳulaġından aḳsımaz dėmişler.

143. Deve çökünce yẻr bulur dėmişler.

144. Șaḳıı deve depmesinden demişler

145. Ne şīrī şutūr ne bīdār-i pütūr dèmişler.

146. Her ag̉lamanuñ gülmesi ve her gülmenüñ bir ag̉laması dèmişler.

147. At ḥuyı er ḥuyı dèmişler.

148. Faḳīüñ og̉lı olmadan ekābirüñ ḳulı olmaḳ yegdir dèmişler.

149. Yarınki țavuḳdan bugünki yumurda yegdür dèmişler.

150. Nākes ile cömerdüñ harcı birdir dėmişler.

151. Ādemüñ alçaġı yörük, yemişüñ alçaġı erik olur dèmişler.

152. At binenüñ ḳ1lı̧ ḳuşananuñdur dėmişler.

153. Șu küçügüñ ${ }^{28}$ söz büyügüñdür ${ }^{29}$ dèmişler.

27 Sözcük "اكملي" şeklinde yazılmış olmasına rağmen bağlamdan dolayı ekmegi şeklinde okunmuștur.

28 Metinde ن ile yazılmıştır.

29 Metinde ن ile yazılmıştır. 
154. Sipāhīye tọgrn cevāb tīmārdan yegdir dėmişler.

154. Sözi sipāhīyāne söyle dẻmişler.

156. Yèrüñ kulaġı vardır dėmişler.

157. Bir dost bir post dèmişler.

158. Er iḳrarından hayvan yularından dèmişler.

159. Çaġırılmayan yère varma dèmişler

160. Da'vete icābet [gerek] dèmişler.

161. Yag̉lı ḳazana yağlı ḳızan dèmişler.

162. Baş yitirecek gerçeḳden baş bitirecek yalan yegdir dèmişler.

163. Söz var baş bitürür söz var baş yitürür dėmişler.

164. Yere baḳan aḥmaḳ dèmişler.

165. Gemiyi kāġıdda, șuyı bardaḳda dèmişler.

166. Kadem eri degilseñ bārī ḳadem erine yoldaş ol dèmişler.

167. Ag̉zuña șig̉acaḳ loḳma al dėmişler.

168. Yarına ḳalan belādan ḳorḳma dèmişler.

169. Hiç olmasa șarug̉ına danış dėmişler.

170. 'Aḳılsız dostdan 'aḳıllı düşmān yegdir dèmişler.

171. Ḳı anaya çeker er dayıya dèmişler.

172. El el üzerindedir tā 'arşa çıḳınca dèmişler.

173. El ilen gelen dügün bayramdır dèmişler.

174. Șayısını bilmez ḥerifüñ ḳoyunını gütme dèmişler.

175. Yüz vėrme [ayıya] gelür ș*çar halıya dèmişler.

176. Leglegüñ 'ömri laḳlaḳla geçer dèmişler.

177. Kebāb ḳanlu yigit canlu gerek dẻmişler.

178. Anasını gör ḳızın al kenārın gör bezin al dèmişler.

179. Ķorda yüri tozuñ belürtme ḳarda yüri izüñ belürtme dèmişler.

180. Düt demege țuțaḳ gerekdir dèmişler.

181. Küpe küp dèseñ küp de düp dèr dèmişler.

182. Ṭoñuzuñ ḳuyruġın kesseñ gine toñuzdur dèmişler.

183. Yemişüñ eyüsini țoñuz yèr dèmişler.

184. Ṭoñuz ḳurbāna yaramaz dėmişler.

185. Țatlu dil ilanı ininden çıḳarur dèmişıler.

186. Olur olmaz ḳo ... bıyık țutma dèmişler.

187. Üzüm birbirisini görerek ḳararur dèmişler.

188. Dilden gelen elden gelmez dèmişler.

189. Beş parmaḳ düz olmaz dėmişler.

190. Balçıg̀ı dīvara ur yapışmazsa izi ḳalur dèmişler.

191. Yārānuñ bir eyitdügine iki ètdügine ḳalma dèmişler.

192. Bir sürçen atın başını kesme dèmişler.

193. Filān yėrüñ șomunı büyükdür dėyüp vațanuñ beritme dèmişler.

194. Az țama' çoḳ ziyān dėmişler.

195. Arıyı sevindirmeyince balın alma dèmişler.

196. Ṣu uyur düşmān uyumaz dėmişler.

197. Karıncayı merdāne gör dèmişler

198. Herkesüñ ḳalbinde bir arslan yatur dèmişler.

199. Evdeki hesāb pāzāra uymaz dèmişler.

200. Kişi ${ }^{30}$ țama $k$ ārdır, güni müflis olur.

201. Evde lāzım iken mescide harāām dèmişler.

202. Ucuz etin çorbası țatsuz olur dèmişler.

203. İki kedi bir arslana pesdir demişler.

204. Peynir șuyı bul[an]dırur dèmişler.

205. Yüküñ ḳoz ise ... dèmişler.

206. Çalḳuya göre oynamaḳ gerek dėmişler.

207. Olur olmaz 'ayb ḳażı ḳızında da olur dèmişler.

208. El-ḥużūr fi' 'l-yataḳ velev kāne. fi'l-baṭaḳ dèmişler. $^{31}$

209. Țaş yẻrinde ag̉ır olur dèmişler

210. Vardugiuñ vilāyet halḳınuñ gözleri kör ise sen dahı bir gözüñi ḳapat dèmişler.

211. Kutlu gün dog̉uşdan bellüdür dėmişler.

212. Penbe ile ateşüñ oyunı olmaz dèmişler.

213. Öksüz og̉lan göbegini kendi keser dèmişler.

214. Her yara șāhibinini acıdır dèmişler.

215. Bir al ata bir genç bege hiżmet etmek güçdür dèmişler.

216. Yārān haṭ̣ı içün piş[me]miş țavuḳ yẻnür dèmişler.

217. Kozı ḳıran yèr dèmişler.

218. On yaşında ḳız ya erde ya yèrde dèmişler.

219. [Kör] ölünce badem gözli olur dèmişler.

220. Yügrük at kendü yėmini [artu]rur dèmişler.

221. Eylüge eylük olaydı [ḳoca] öküze bıçaḳ

olmaz dèmişler.

222. Silinmiş kişiye eylük eylemek eyü kişiye masharalık eylemek gibidir dèmişler.

223. Aḳ aḳçe ḳara gün içindir dèmişler.

224. Aḳçası [bol] olanuñ baḳma yüzi ḳarasına daḩı dèmişler.

225. Kuyıyı şöyle ḳaz kim kendüñ de düşersen çıł̣maḳ kābil ola dèmişler.

226. [Ṣabr] selāmet, evmek melāmet dèmişler.

227. Silinmiş ag̉zı egri egse senden bellüdür silinmiş demişler.

228. 'Arabuñ yaġı çoḳ olunca $d$ *şaḳlarına da sürer dèmişler.

30 Metinde șeklinde yazılmış olmasına rağmen bağlamdan kişi olması gerekmektedir.

31 Bataklıkta bile olsa yatakta huzur vardır. 
229. Şol ['aḳrebe] niçün egri yürürsün dėyü [424a] èyidene yigidim nice yürürsem yẻr üstü dèyü cevāb vèmiş dėmişler.

230. Şerīatı hōr gören hōor olur dèmişler.

231. Bașduguñ̃ boġazlama, ḳaçanı ḳoma demişler.

232. Türke beglik vėrilince evvel babasını aṣar dèmişler.

233. Türküñ 'aḳlı șoñra gelür dèmişler.

234. Bıçaḳ kendü șapın kesmez dèmişler.

235. Helāl-zāde bāzār yapar, ḥarām-zāde bāzār bozar dèmişler.

236. Davul yegdir zurnadan dèmişler.

237. Davuluñ sesi yeg gelür uzaḳdan dèmişler.

238. Ġarīblikde öyünmek ḥammāmda türki irlamak meşhūrdur dèmişler.

239. Oș*ruk g*te, arpa [ekmegi] bahānedir dèmişler.

240. Șag̉ öküze eski șamān bahānedir dèmişler.

241. Oynamag̉a göñli olmayan ḳız yẻrim țar dèr dèmişler.

242. Ṭavuḳ șuyı içer göge baḳar dėmişler.

243. Aç țavuḳ kendüyi düşinde dāyimā taḥıl bāzārında görür dèmişler.

244. Her ziyān bir fend, ne ziyān tükenür ne fend dèmişler.

245. Dügün aşı $b * k s s u z$ olmaz dėmişler.

246. Yemişini ye ag̉acını șorma demişler.

247. Yüz yüzden utanur dėmişler.

248. Koç ḳurbān içindir dèmişler.

249. Dag̉ tenhādır dèyü oṣ*rma bir sikime deyer bulunur dèmişler.

250. Kargaayı besle gözüñ oymaya gerek olur dèmişler.

251. Bilmedügüñ ḥayvānuñ ardına geçme dèmişler.

252. Sözi vèrenden alan uṣlı gerekdir dėmişler.

253. Köçekden al haberi dèmişler.

254. Kapuyı yarduñ odun oldı, ḥalāyığı s*kdüñ ${ }^{32}$ ḳadın oldı dèmişler.

255. Șarrāf bilür altunuñ ḳıymetini dèmişler.

256. Ķııım saña dirim gelinim sen işit dèmişler.

257. Helvācı ḳızı dahıı țatlu dèmişler

258. Șaġır oṣ*rdug̉ını işitmez sevinür dèmişler.

259. Kesmedügün ${ }^{33}$ eli öp başuña ḳo dèmişler.

260. Borçlu olmaz beñzi șararur dèmişler.

261. Köçek ile yola gitme yüküñ yıḳılursa güler, yüki yıḳılursa ag̉lar dèmişler.

262. 'Ayb[sız] yār isteyen yārsız, ḳılsız *m

32 Metinde ن ile yazılmıştır.

33 Metinde ن ile yazılmıştır. [isteyen] *msız ḳalur dèmişler.

263. [Tèz biten tėz yèter] șuda biten șuda yèter [dèmişler].

264. Yiyemeyecegüñ ag̉aca ḳaşınma [dėmişler]

265. Eski yār eski ḥammām dẻmişler.

266. Șuyı getüren de bir destiyi ḳıran da birdir dèmişler.

267. El atduġ țaş uzaḳ gider dėmişler.

268. El içün ag̉layan gözsüz ḳalur dèmişler.

269. Ölen $s * k i$ ag̉layan büzügine dèmişler.

270. Kurı s*k düşmān büzügine dėmişler.

271. Kurı yanınca yaş da yanar dèmişler.

272. 'Araba ḳırılınca yol gösterici çog olur dèmişler.

273. Kayṣeriyye heseāb ile yapılmış dèmişler.

274. Öyleden șoñra herīse ucuz olur dèmişler.

275. Ocak egriligi żarar etmez, tüteni tọgrı çıḳsun dèmişler.

[424b]

276. C1ḳacak cāna diñlenecek yer gerekdir dẻmişler.

277. Er loḳması bahāneyle yenür dėmişler.

278. Belāsız bal olmaz dẻmişler.

279. Bal tutan parmaġın yalar dèmişler.

280. Devlet ḳażā yanındadır dèmişler.

281. Serçeden ḳorḳan țaru ekmez dèmişler.

282. Serçeye çubuk beredir dèmişler.

283. Sarhōōs baş hōọ dėmişler.

284. Silinmiş esen gerek evde gerek dèmişler.

285. Silinmiş ahır öñinden geçme fışḳı taşıdırlar dèmişler.

286. Dostla [ye] iç alışvèriş etme dėmişler.

287. Șaḳınılan göz, çöp düşkün olur dèmişler.

288. Kork Allah'dan korḳandan, kork Allah'dan korḳmayandan da dèmişler.

289. Hayr işe te'hīr cāyiz degüldür dèmişler.

290. İşüñ issi yelinde çıḳar dėmişler.

291. Biñ gün yıraḳ bir gün gerek dèmişler.

292. Geregi gerekmez iken dèmişler.

293. İmām * șurınca cemā'at neylemek gerek dèmişler.

294. Yoluñ otı babanuñ buțı dèmişler.

295. Kelüñ $g * t i$ aksag̉un *mı dèmişler.

296. Nașībüñ var ise gelür Yemen'den dèmişler.

297. Nașībli yèr kötegi dèmişler.

298. Ekmegi yiyen bilmez, toggrayan bilür dėmişler.

299. İki şāhidle bir hịșār alunur dèmişler.

300. Nekbete borçlu olma, olur olmaz yėrde ister dèmişler.

301. Kurbetlikde rüsvāylık çoḳ olur dėmişler.

302. Genç iken evlenen șabāḥdan ḳarnın țoyuran 
aldanmaz dèmişler.

303. Aylaḳ oturmadan aylaḳ iş işlemek yegdir dèmişler.

304. Uzun șaḳallu aḥmaḳ ḳıșa boylı fitne (hayru'lumūr ev sațuhā $\overline{\bar{s}}^{34}$ ) dèmişler.

305. Kușșadan hịșṣe dèmişler.

306. Yè iç ḩarmanda ḳatır ürkütme dėmişler.

307. Nașịhat-1 çobān rāḥat-1 beden dèmişler.

308. Hasta oñmaduġı kelinen oñmaduġı $\mathrm{s}$ *ke șıçar dèmişler.

309. Kahṭtlıḳda b*ḳını yiyen ucuzlıḳda utanur dèmişler.

310. Șuç öldürenüñ degül, ölenüñdür [dèmi]şler.

311. 'Āşı̣ olmaz iseñ silinmiş yelten dèmişler.

312. Zamānda silinmiş $\mathrm{s}$ *ken utanur dèmişler.

313. Bag̉dād uzaḳ degüldür dėmişler.

314. Silinmişde ḳaçmaḳ erlikdir dėmişler.

315. Erlik on țoḳuzı hịledir demişler.

316. Țutulmaduḳ ug̉rı begden tọgrı dèmişler.

317. Altı ay s*k uzar altı ay daḥı ț şaḳ uzar dèmişler.

318. Țatluyı țatlu söyle dèmişler.

319. Gördügün ${ }^{35}$ ört, görmedügün ${ }^{36}$ söyle dėmişler.

320. Yalıñuz ḳażıya varan șaḳalını șıgarıraḳ çıḳar dèmişler.

321. Bir sözi söyledügüñ ${ }^{37}$ vaḳtüñ ${ }^{38}$ öñüñe baḳ da söyle dèmişler.

322. Er evine uça deg gemi başdan ḳıça $\operatorname{deg}^{39}$ dèmişler.

\section{[425a]}

323. Egreti ata binen tīz iner dèmişler.

324. Nevbet degirmende olur dèmişler.

325. Ne ḳadar et arıḳ ise ekmek üstinde yaraşur dèmişler.

326. Müft sirke baldan țatludur dèmişler.

327. B*k yemek mi‘deye bağludur dèmişler.

328. Tuzsuz aşım ḳavuḳsız başım.

329. Varuşuña gelişim tarhana bulguur aşxm ki bāşed ki ne bāşed ${ }^{40}$ dèmişler.

330. Çoḳ nāz 'āşıḳı uṣandurur dẻmişler.

331. Yavrı ḳuşuñ ag̉zı büyük olur.

332. Ṣabr-1la ḳoruk hẹelvā tud yaprag̉ı aṭlās olur dèmişler.

34 "İşlerin hayırlısı orta olandır" anlamına gelen hadis.

35 Metinde ن ile yazılmıştır.

36 Metinde ن ile yazılmıştır.

37 Metinde ن ile yazılmıştır

38 Metinde ن ile yazılmıştır

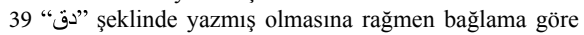
deg olmalıdır.

$40 \mathrm{Ne}$ olur ne olmaz.
333. Türk işi oduncı olur dėmişler.

334. Karınca ḳaderince dèmişler.

335. Șabr selāmet evmek melāmet dèmişler.

336. Gönülsüz s*kişüñ gözsüz og̉lı olur dèmişler.

337. Öküz düşünce bıçaḳ çıḳarur çoḳ olur dėmişler.

338. Dilencinüñ yüzi ḳara, țorbası țolu dèmişler. 


\section{Sonuç}

İncelenen mecmuanın içinde yer alan, "uzun deneme ve gözlemlere dayanılarak söylenmiş ve halka mâl olmuş, öğüt verici nitelikte söz"41 tanımına uygun 338 tane atasözü bulunmaktadır. Bu asl dahı atalarsözü beyânındadır zikr olunur başlığı altında mecmuanın der-kenârında bulunan atasözleri herhangi bir abece sıras1 gözetilmeksizin yer almaktadır. Bununla beraber atasözlerinin, iki başlık altında tasnif edildiklerini söylemek yanlış olmayacaktır. İlk kısımdaki atasözlerinin tamamının yüklemi olumsuz çekimlenmiştir (ilk atasözü istek kipi ile çekimlenmiştir.): Güçle gökçeklik olmaz, Yaliñuz țaş dīvār olmaz, Yalıñuz elin sesi çı kmaz vb.; ikinci kısımdakilerin tamamı da "demişler" yüklemiyle kurulmuştur: Egreti ata binen tīz iner dèmişler, Nevbet degirmende olur dèmişler, Ne kadar et arlk olsa ekmek üstinde yaraşur dèmişler $\mathrm{vb.}$

Atasözlerinde düzenli bir tematik tasnifin yapılmadığı göze çarpmakta ise de bir kısmının tablo 1'de de görüleceği üzere bazı temalarda sınıflandırılmaya çalışıldığ 1 görülmüştür. Tematik olarak sıralanan atasözlerinin toplam atasözlerine oranı ise \% 21 olarak karşımıza çıkmaktadır.

İncelenen atasözlerinin önemli bir kısmı yapısal olarak basit cümle biçimindedir. Az da olsa fiilimsilerle, muhtelif bağlaçlarla ve son olarak da birkaç sıralı birleşik cümleyle kurulmuş atasözlerine rastlanmaktadır.

XVII. yüzyıla ait bu atasözlerinin toplumun muhtelif tabakalarından derlendiği kullanılan dilden anlaşılmaktadır. Eğer ki atasözlerini derleyen Ahmed bin Musa bunları sadece belli seçkin bir tabakadan derleseydi bu kadar rahat ifade şekillerinin yer aldığı atasözleri bu seçkide bulunmazdı. Çünkü seçkin tabakada sövgü kullanılır, ancak bunlar belli bir edep gözetilerek yazılırdı. Atasözlerinde görülen çok sayıda sövgü sözleri ve kaba ifadeler toplumun her kesiminin kullandığı atasözlerinin yazıya geçirildiğinin göstergesidir. Seçkin tabakadan derlediği atasözlerine ise Arapça ve Farsça ibarelerin yer aldığ örnekler gösterilebilir. Bu da atasözlerinin, yukarıda belirttiğgimiz gibi farklı tabakalardan alındığının önemli bir göstergesidir.

41 Çevrimiçi: http://www.tdk.gov.tr/index.php?option=com bts\&arama=kelime\&guid=TDK. GTS.5bbc6dae72a342.87954435 $(15.09 .2018)$ 


\section{Kaynakça}

Aksan, Doğan, Her Yönüyle Dil Ana Çizgileriyle Dilbilim, Ankara, TDK Yayınları, 1998.

Aksoy, Ö. Asım, “Atasözleri, Deyimler”, TDA Yıllığı Belleten, 1962, TDK Ya: 217, Ankara, 1988, ss. 131-166.

, Gaziantep Ağzında Atasözleri, TDK, Ankara, 1941.

Albayrak, Nurettin, Türkiye Türkçesinde Atasözleri, Kapı Yayınları, İstanbul, 2009.

Ceyhan, Âdem, “17. Asra Ait İki Kitapçık: Nasreddin Hoca Hikâyeleri ve Türk Atasözleri”, CBÜ Sosyal Bilimler Dergisi, Cilt 9 S 2, Ekim 2011, s. 121-160.

, "Bazı Yazma ve Basma Türk Atasözü Derlemeleri”, Dil ve Edebiyat Araştırmaları, s. 4, Yaz 2011, ss. 175-225. , “Eski Bir Türk Atasözleri Kitabı”, Bir, sayı 9-10, İstanbul, 1998, ss. 109-132.

Dilçin, Dehri, Edebiyatımızda Atasözleri, Klişecilik ve Matbaacılık T.A.Ş., İstanbul 1945.

Elçin, Şükrü, Halk Edebiyatı Araştırmaları 2, Ankara, Akçay Yayınları, 1997.

Erenoğlu, Dilek, “Güvâhî’den Günümüze Atasözleri ve Deyimler”, Turkish Studies, vol 2/4, 2007, ss. 1150-1167.

Eyüboğlu, E. Kemal, Şiirde ve Halk Dilinde Atasözleri ve Deyimler, Doğan Kardeş Matbaac1lik, İstanbul, 1973.

İbrahim Şinasi Efendi, Durub-ı Emsal-i Osmaniye, İstanbul, 1302.

Karpuz, Hacı Ömer, “Türk Atasözlerindeki Yapısal Benzerlik Üzerine Dizibilim ve Dizimbilim Bakımlarından Bir İnceleme”, I. Dil, Yazın, Deyişbilim Sempozyumu, Denizli, 5-7 Nisan 2001, ss. 236-242.

Kartallığlu, Yavuz, Klasik Osmanlı Türkçesinde Eklerin Ses Düzeni, Türk Dil Kurumu Yayınları, Ankara 2015.

Tülbentçi, Fazıl, Türk Atasözleri ve Deyimler, İnkilap ve Aka Kitabevleri, İstanbul, 1963 